\title{
EFFECTS OF CHRONIC EXPOSURE TO CADMIUM ON STATE OF HEALTH AND CUMULATION IN TISSUES OF CALVES
}

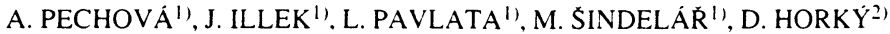 \\ ${ }^{1)}$ Clinic of Diseases of Ruminants, Faculty of Veterinary Medicine, University of Veterinary and Pharmaceutical \\ Sciences, Brno. Czech Republic \\ ${ }^{2}$ Institute of Histology and Embryology, Faculty of Medicine, Masaryk University, Brno. Czech Republic
}

Received March 23, 1998

Accepted August 19, 1998

\begin{abstract}
Pechová A., J. Illek, L. Pavlata. M. Šindelář. D. Horký: Effects of Chronic Exposure to Cadmium on State of Health and Cumulation in Tissues of Calves. Acta vet. Brno 1998, 67: 167-174.

Effects of environmental conditions and long-term administration of low doses of cadmium on state of health and cumulation in tissues of calves were investigated. A set of 18 calves, kept in an ecologically favourable area, was divided into 3 groups (Groups I-E1 and I-E2 received $1 \mathrm{mg}$ and $2 \mathrm{mg}$ cadmium per animal per day, respectively. Group I-C were controls). Cadmium was administered orally as a cadmium chloride solution for 92 days. Another set of 16 calves, kept in an industrial area, was divided in two groups (Group II-E received $1 \mathrm{mg}$ cadmium per animal per day, Group II-C were controls). Cadmium was administered as given above for 106 days. Three calves of each group (only two calves of Group II-C) were slaughtered at the end of the administration period and hepatic, renal, myocardial, diaphragmatic, skeletal muscular, small intestinal, pancreatic, and testicular samples were collected for the determination of cadmium using the ETA AAS method. Blood samples were also collected during the experiment for the determination of metabolic profiles (total proteins, urea, glucose, aspartate amino transferase [AST], and gamma glutamyl transferase [GGT]). The administration of cadmium had no effect on metabolic profiles. The only observed change was a non-significant increase in AST activity in the exposed calves. The following mean concentrations of cadmium ( \pm SD), expressed in $\mu \mathrm{g} \cdot \mathrm{kg}^{-1}$ fresh tissue, were found in the groups I-C, I-EI, I-E2, II-C and II-E: kidney 35.2 $\pm 7.8,326.0 \pm$ $114.5,385.7 \pm 61.4,129.4 \pm 6.8$, and $1618.7 \pm 393.2$, respectively: liver $16.5 \pm 5.6,113.5 \pm$ $53.8,138.4 \pm 32.6,28.3 \pm 6.4$. and $465.3 \pm 141.5$, respectively: pancreas $2.6 \pm 0.3,13.8 \pm 3.6$, $20.5 \pm 6.6,8.0 \pm 0.3$, and $57.1 \pm 16.5$, respectively; testicle $3.4 \pm 0.6,8.9 \pm 2.4,6.8 \pm 0.6,2.9$ \pm 1.4 , and $27.2 \pm 0.7$, respectively; small intestine $6.1 \pm 1.6,15.1 \pm 9.5,31.6 \pm 22.8,3.8 \pm 3.3$, and $17.7 \pm 6.1$, respectively; myocardium $0.6 \pm 0.1,1.7 \pm 1.0,2.8 \pm 0.4,0.9 \pm 0.1$, and $4.6 \pm$ 0.2 . respectively; diaphragm $0.3 \pm 0.2,2.1 \pm 0.7 .3 .9 \pm 0.9 .2 .4 \pm 1.4$, and $3.5 \pm 0.1$, respectively; skeletal muscle $0.7 \pm 0.2,2.1 \pm 1.0 .2 .4 \pm 1.0 .1 .1 \pm 0.2$, and $3.2 \pm 1.9$, respectively. The differences in hepatic, renal, pancreatic and testicular concentrations between the experimental and the appropriate control groups were significant. Except for the small intestine, the tissue concentrations of cadmium were influenced by environmental conditions apparently more than by the administration of cadmium. Chronic exposure to low doses of cadmium had no adverse effect on the state of health.
\end{abstract}

Cadmium, cattle, liver, kidneis, skeletal muscles, mocardium, diaphragm, testicles, small intestine, environment, metabolic profile

The increase in the concentrations of hazardous elements in the environment has become a serious problem. Cadmium ranks with the toxic environmental pollutants. It has been 
demonstrated that its concentration in tissues (in particular kidneys. liver. testicles, pancreas) increases with advancing age (Antoniou 1990; Pechová et al. 1998) and that it does not penetrate through placenta into foetal tissues ( $\mathrm{Smith}$ et al. 1991 ab).

Monitoring of cadmium concentrations in various tissues is important not only in respect of state of health and occurrence of disorders of calcium. copper, zinc, selenium, and iron metabolism (Ohta et al. 1993; Cibulka et al. 1986; Illek and Dočekalová 1993), but also in respect of human nutrition and possible health hazards. Attention is also paid to the distribution of cadmium in individual tissues on the microscopic and submicroscopic levels (Horký et al. 1997: Horký et al. 1998).

The objective of our experiments was to assess the effect of long-term oral exposure to low doses of cadmium on state of health and its concentrations in various tissues and organs of calves kept in areas differing in the burdens of industrial emissions.

\section{Materials and Methods}

Experiment I was conducted in the ecologically favourable area of the Bohemian-Moravian Highlands and Experiment II in the area of Ostrava heavily polluted by industrial emissions.

In Experiment I. 18 Black-Pied calves aged 14 days to 1 month were divided into three groups. Groups I-El and $\mathrm{I}-\mathrm{E} 2$ received $\mathrm{I} \mathrm{mg}$ and $2 \mathrm{mg}$ cadmium per animal per day. respectively. The calves of Group I-C served as control animals. Cadmium was administered for 92 days and the total doses for I-El and I-E2 were 92 and $184 \mathrm{mg}$ cadmium per animal.

Experiment II was conducted in 16 Black-Pied calves aged 14 days to 1 month. divided into two groups. Group II-E received $1 \mathrm{mg}$ cadmium per animal per day and the calves of Group II-C served as controls. Cadmium was administered for 106 day's and the total dose was $106 \mathrm{mg}$ per animal.

In both the experiments. cadmium was added to milk in the form of a $0.16 \%$ solution of cadmium chloride. Drinking of milk was checked to ensure the intake of the whole dose of cadmium. Three calves of each group (only two calves of Group II-C) were slaughtered at the end of the administration period and samples of the caudal liver lobe. renal cortex. myocardium (apex cordis). diaphragm (costal part). skeletal muscle (m. semimembranosus), small intestine. pancreas. and testicles were collected. The samples were immediately frozen and stored at $-20^{\circ} \mathrm{C}$ until analysed. The analysis consisted of digestion in the microwave oven MILESTONE and determination of cadmium by the ETA AAS method using the apparatus SOLAR 939 (UNICAM).

State of health was checked during the experiments by current clinical examinations and blood samples were collected from $v$. jugularis for the determination of metabolic profiles at monthly intervals. The following values were measured in blood plasma: total proteins. urea. glucose. AST and GGT. The blood analyses were made using the automatic analyser COBAS MIRA and standard methods. AST and GGT activities were determined as described by Malý et al. (1989) and Zahradníček et al. (1986). respectively. The results were processed by variance analysis ANOV.A. Student's t-test and correlation analysis using the software EXCEL Version 6.0.

\section{Results and Discussion}

Clinical examinations did not reveal considerable impairment of state of health in any of

Table 1

Catalytic concentrations of AST and GGT in blood plasma of calves kept the ecologically favourable region (means $\pm \mathrm{SD}$ )

\begin{tabular}{|c|c|c|c|c|c|}
\hline & & 12. 9. & 5.10. & 24.10. & 23.11. \\
\hline AST & Control & $0.94 \pm 0.20$ & $1.11 \pm 0.11$ & $1.97 \pm 0.75$ & $2.06 \pm 0.55$ \\
\hline ukat. & $C d(1 \mathrm{mg})$ & $1.41 \pm 0.98$ & $1.33 \pm 0.26$ & $2.52 \pm 1.17$ & $2.54 \pm 0.99$ \\
\hline & $\mathrm{Cd}(2 \mathrm{mg})$ & $1.14 \pm 0.11$ & $1.28 \pm 0.11$ & $2.65 \pm 1.18$ & $2.57 \pm 1.31$ \\
\hline GGT & Control & $0.44 \pm 0.06$ & $0.24 \pm 0.06$ & $0.27 \pm 0.09$ & $0.22 \pm 0.03$ \\
\hline$\mu \mathrm{kat} \cdot \mathrm{I}^{-1}$ & $\mathrm{Cd}(1 \mathrm{mg})$ & $0.47 \pm 0.09$ & $0.28 \pm 0.05$ & $0.27 \pm 0.06$ & $0.23 \pm 0.09$ \\
\hline & $\mathrm{Cd}(2 \mathrm{mg})$ & $0.39 \pm 0.08$ & $0.23 \pm 0.03$ & $0.32 \pm 0.06$ & $0.26 \pm 0.05$ \\
\hline
\end{tabular}

$* \mathrm{P}<0.05$ 
Table 2

Catalytic concentrations of AST and GGT in blood plasma of calves kept in the industrial region (means \pm SD)

\begin{tabular}{|l|l|lll|}
\hline \multicolumn{2}{|c|}{} & 17.8. & 14.9. & 12.1. \\
\hline \multirow{2}{*}{$\begin{array}{l}\text { AST } \\
\text { Mkat } \cdot 1-1\end{array}$} & Control & $0.97 \pm 0.17$ & $0.92 \pm 0.12$ & $1.10 \pm 0.22$ \\
\cline { 2 - 5 } $\begin{array}{l}\text { GGT } \\
\mu \mathrm{kat} \cdot \mathrm{I}^{-1}\end{array}$ & $\mathrm{Cd}(\mathrm{I} \mathrm{mg})$ & $0.79 \pm 0.15$ & $1.11 \pm 0.47$ & $1.44 \pm 0.25^{*}$ \\
\cline { 2 - 5 } & $\mathrm{Cd}(1 \mathrm{mg})$ & $0.52 \pm 0.05$ & $0.38 \pm 0.12$ & $0.21 \pm 0.02$ \\
\hline
\end{tabular}

$* \mathrm{P}<0.05$

Table 3

Statistical significance of differences in concentrations of cadmium among individual groups of calves (t-test)

\begin{tabular}{|l|c|c|c|c|c|c|c|}
\hline & I-K/I-PI & I-K/I-P2 & I-K/II-K & II-K/II-P & I-P1/I-P2 & II-P/I-PI & II-P/I-P2 \\
\hline Liver & $*$ & $* *$ & - & $*$ & - & $*$ & - \\
\hline Kidney & $*$ & $* *$ & $* *$ & $*$ & - & $*$ & $*$ \\
\hline Muscle & - & - & - & - & - & - & - \\
\hline Diaphragm & $*$ & $* *$ & - & - & - & - & - \\
\hline Myocardium & - & $* *$ & - & $* *$ & - & $*$ & - \\
\hline Pancreas & $* *$ & $* *$ & $* *$ & $*$ & - & $*$ & $*$ \\
\hline Testis & $*$ & $* *$ & - & $* *$ & - & $*$ & $* *$ \\
\hline Intestine & - & - & - & - & - & - & - \\
\hline
\end{tabular}

$* * \mathrm{P}<0.01 * \mathrm{P}<0.05-$ nonsignificant difference

I-C control - clean area

I-E2 experimental group $(2 \mathrm{mg} \mathrm{Cd})$

I-El experimental group $(1 \mathrm{mg} \mathrm{Cd})$

II-E experimental group ( $1 \mathrm{mg} \mathrm{Cd})$

II-C control - industrial area

Table 4

Correlation coefficients for concentrations of cadmium in selected tissues

\begin{tabular}{|l|c|c|c|c|c|c|c|c|}
\hline & Liver & Kidney & Pancreas & Testis & Myocardium & Diaphragm & Muscle & Intestine \\
\hline Liver & 1 & & & & & & & \\
\hline Kidney & $0.99^{* *}$ & 1 & & & & & & \\
\hline Muscle & $0.99^{* *}$ & $0.99^{* *}$ & 1 & & & & & \\
\hline Diaphragm & $0.96^{* * *}$ & $0.97^{* *}$ & $0.95^{* *}$ & 1 & & & & \\
\hline Myocardium & $0.87^{* *}$ & $0.84^{* *}$ & $0.88^{* *}$ & $0.89^{* *}$ & 1 & & & \\
\hline Pancreas & 0055 & 0.53 & 0.57 & 0.57 & $0.69^{*}$ & 1 & & \\
\hline Testis & 0.68 & 0.66 & 0.74 & 0.60 & $0.66^{*}$ & 0.55 & 1 & \\
\hline Intestine & 0.17 & 0.17 & 0.22 & 0.15 & 0.39 & 0.42 & 0.43 & 1 \\
\hline
\end{tabular}

$*$ P $<0.01 * \mathrm{P}<0.05$

the calves receiving 1 or $2 \mathrm{mg}$ cadmium per animal per day. The total protein and glucose concentrations were within physiological limits throughout the experiments and no significant differences were found among the groups. The concentration of urea varied within the normal range of 2.5 to $5.0 \mathrm{mmol}^{-\mathrm{I}^{-1}}$ ( V rzgula et al. 1990) in Experiment I and was moderately increased in both groups of Experiment II. This increase, however, reflected only the composition of ration and was not associated with the exposure to cadmium. Certain variations were observed in the activities of enzymes indicating a damage to hepatic parenchyma. In Experiment II, the catalytic concentration of AST in blood plasma of the calves receiving cadmium was increased from the 2 nd month. The situation was more complicated in Experiment I in which the activity of AST was increased in both the experimental and the control calves and the increase was somewhat more marked in the experimental than in the control animals. Since the catalytic activity of AST reached 2 to $3 \mu \mathrm{kat} \cdot \mathrm{l}^{-1}$, we assume that the increase must have been due to lesions in some other tissues (such as skeletal muscles), in which the ubiquitary enzyme AST is also present. However, the lesions did not apparently results from the administration of cadmium, because increased activity was found also in the control group. The catalytic activity of GGT ranged between 

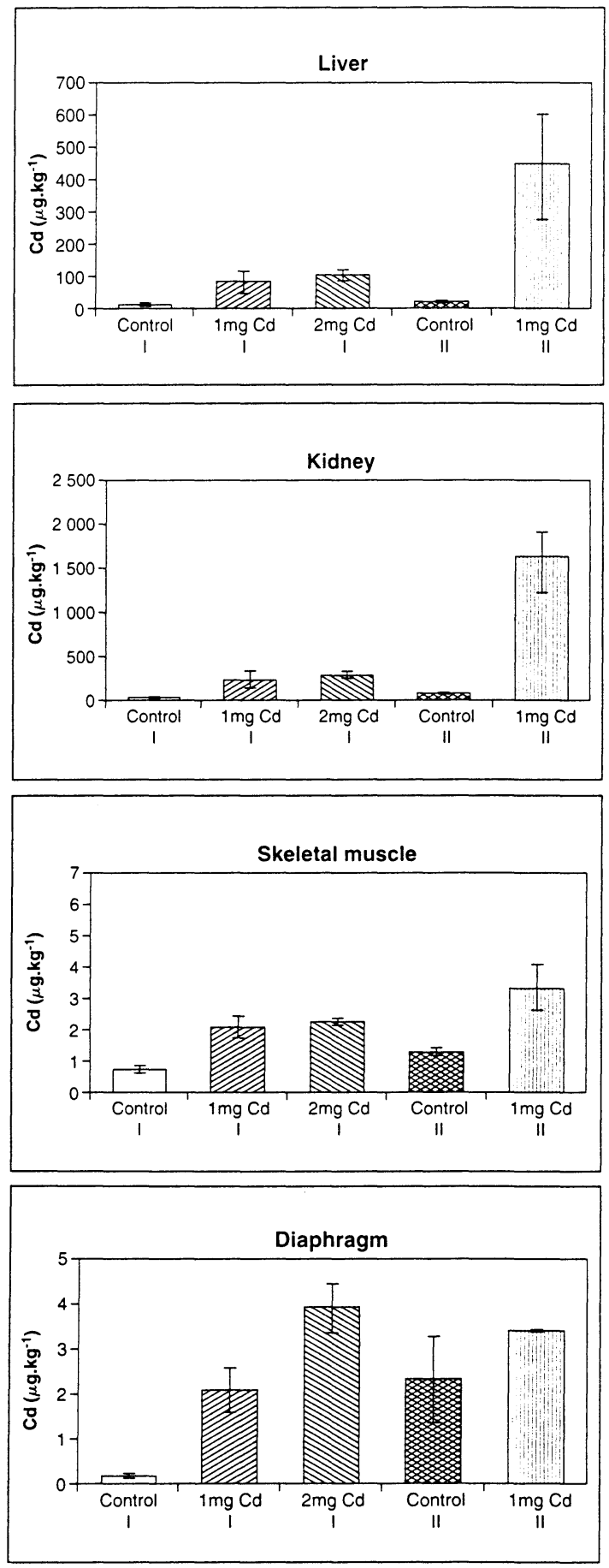

Figs 1-4. Cd concentrations in tissues of calves (mean $\pm S D$ ).
0.2 and $0.5 \mu \mathrm{kat} \cdot \mathrm{I}^{-1}$. i.e. within the physiological limits for cattle (Pechová 1993), in all the calves under study. Apparently, the lesions developed rather in hepatic parenchyma than in excretory ducts and the impairment of hepatic functions was not significant. Our results are in accordance with the WHO recommendation of 1995 that in humans the intake of cadmium should not exceed $1 \mu \mathrm{g}$ per $1 \mathrm{~kg}$ body weight. Compared with this recommendation. the doses administered in our experiments were approximately 20 or 40 times higher at the initial phase of the experiment and approximately 10 times higher at its end when the body weights exceeded $100 \mathrm{~kg}$. It can be concluded that chronic administration of low doses of cadmium to calves does not damage their health and induces only liver alterations indicated by an increase of the catalytic concentration of AST in blood plasma. Catalytic concentrations of AST and GGT in blood plasma during the administration period are presented in Tables 1 and 2.

Tissue samples collected after slaughter were analysed for the concentration of cadmium. Mean values expressed in terms of $\mu \mathrm{g} \cdot \mathrm{kg}^{-1}$ fresh tissue $( \pm$ S.D. $)$ are presented in Figs 1-8. Differences between the experimental and the control groups were large and significant (see Table 3) although the numbers of the slaughtered calves were low.

It is evident that long-term administration of low doses of cadmium results in the cumulation of this element in individual organs. Like Jorhem et al. (1991) and Kreutzer et al. (1991), we also found the highest cumulation in kidneys. Compared with controls, the concentration of cadmium in renal cortex rose to a 6.3 to 12.5 fold. It shall be noted that the administration 
of the double dose resulted in an only moderate additional increase in tissue cadmium concentration (1.2 to 1.8fold). Similar conclusions were arrived at by Rusek and Čelechovská (1988) who reported retention rates 0.01 and 0.005 for lower and higher doses of cadmium, respectively. Thus the assumption has been confirmed that the absorption of trace and toxic elements is inversely proportional to their concentration in the diet and that the absorbed proportion decreases with increasing intake. A considerable ( 6.9 to 16.5 fold) increase in the concentration of cadmium was also found in hepatic samples. Liver is the major organ of the initial phase of cadmium metabolism and control of biliary excretion (Frazier 1977). Cadmium is detoxified by binding to a specific protein giving rise to metallothioneine. The pattern of renal synthesis is similar. Both in liver and in kidneys, the ratio of thioneine-bound and total cadmium rises with increasing concentrations of the cation in tissues until a critical limit is reached (Webb 1977). The development of signs of toxicity and hepatic lesions depends on the hepatic concentration of cadmium. Cadmium is safely detoxified at low concentrations, but if the concentration rises, it binds with other proteins and signs of toxicity may develop (Underwood 1977).

The concentrations of cadmium in diaphragmatic, myocardial and muscle samples did not exceed $10 \mu \mathrm{g} \cdot \mathrm{kg}^{-1}$. Skeletal muscles, representing a considerable part of body mass, contain an only relatively small part of total cadmium and are well protected against its cumulation (Neathery and Miller 1975). The differences among individual tissues within groups were rather small. Owing to the low dosage, no effects of the intensity
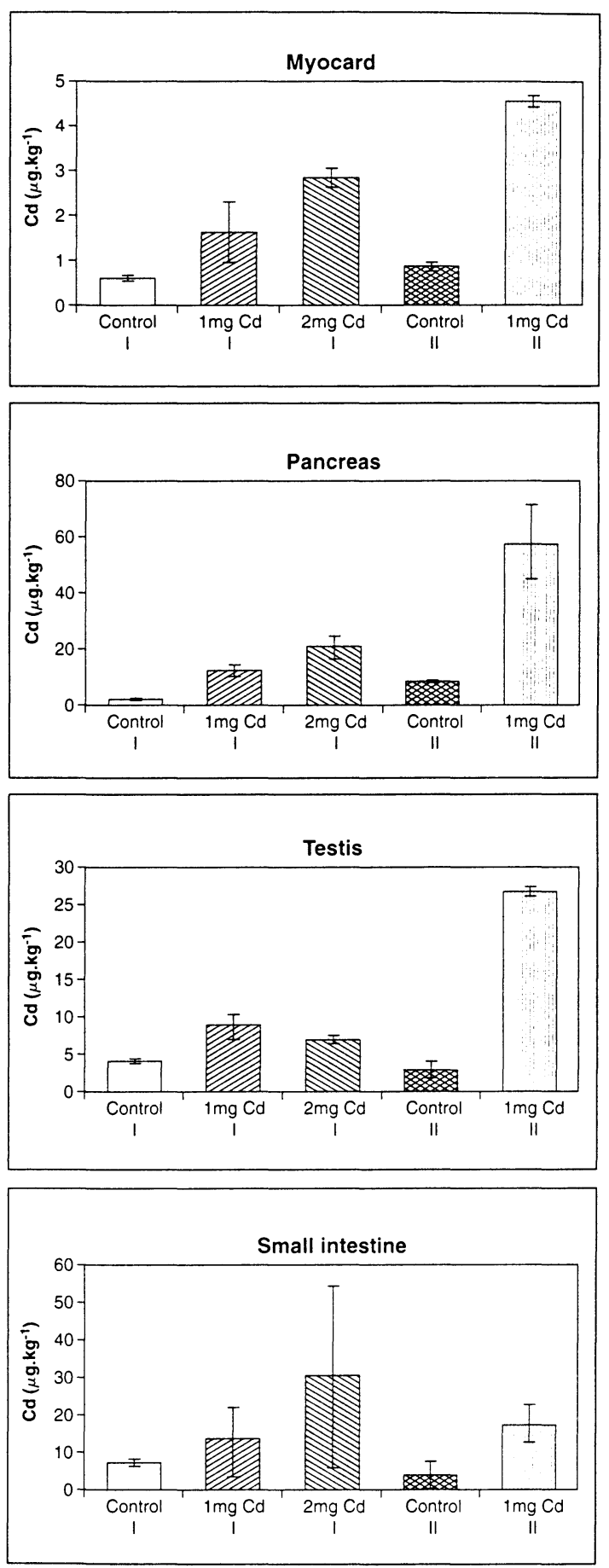

Figs 5-8. Cd concentrations in tissues of calves (mean $\pm S D$ ). 
of blood supply or work load on the concentration of cadmium in muscles were apparent. Nevertheless. the concentrations of cadmium in myocardial tissue were apparently dosedependent. Differences were found between the experimental and the control groups. The difference was significant in diaphragmatic tissue between Groups I-C and I-EI and highly significant in diaphragmatic and myocardial tissue between Groups I-C and I-E2. and in myocardial tissue between Groups II-C and II-E.

Pancreas and testicles rank with organs sensible to the administration of cadmium. The differences between the control and the experimental groups were highly significant or significant.

Unlike in other analysed tissues, the concentrations of cadmium in the small intestine were dose-dependent and no marked differences were found between results of Experiment I and Experiment II. Between-group differences were non-significant owing to a wider variability of results. The concentrations of cadmium in the small intestine were influenced above all by the oral intake. Mean values were similar in control groups and groups receiving $1 \mathrm{mg} \mathrm{Cd}$ per animal per day and twice as high in the group receiving $2 \mathrm{mg} C \mathrm{~d}$ per animal per day. The dependence of the content of cadmium in the small intestine on the way of administration and dosage has been confirmed by Elsenhans et al. (1994). The same authors investigated the cumulation of cadmium in the small intestine incl. the production of metallothionenine (Elsenhans et al. 1995).

Differences in the mechanisms of cadmium cumulation among the analysed tissues are evident from the correlation coefficients presented in Table 4 . The highest correlation coefficients $(r>0.9)$ were found among liver, kidneys pancreas, and testicles. Another group with lower coefficients ( $\mathrm{r}=0.5$ to 0.8 ) included muscular tissues (myocardium, diaphragm, skeletal muscle); highly significant differences were found for myocardium on one hand, and liver, kidneys, pancreas and testicles on the other hand. Non-significant coefficients $(r=0.1$ to 0.4$)$ were found for small intestine and any of the other tissues under study.

Effects of environmental factors on the cumulation of cadmium were demonstrated in all the analysed tissues excepting the small intestine. Although the mean hepatic concentrations of the control groups I-C and II-C were $16.5 \pm 5.6$ and $28.3 \pm 6.4 \mu \mathrm{g} \cdot \mathrm{kg}^{-1}$, the difference was non-significant. A smaller difference in the concentration of cadmium between hepatic and renal tissues was apparently due to differences in metabolic functions of the two organs. Of course. some influence of the small size of the groups shall also be considered. Certain non-significant differences were also found among samples of muscular tissues. The concentrations of cadmium in these tissues did not exceed $4 \mu \mathrm{g} \cdot \mathrm{kg}^{-1}$. At such levels a part of the variance is also due to analytical error, because they approach the detection limit of the method $\left(0.31 \mu \mathrm{g} \cdot \mathrm{kg}^{-1}\right)$. They also indicate that an exposure to low doses does not result in cumulation of cadmium. Mean concentrations of cadmium in the small intestine were similar in both groups, but individual within-group differences were considerable. This finding indicates that a significant role was played by other than oral intake of cadmium.

Marked differences were found between Groups I-El and II-E receiving the same doses of cadmium. In Group II-E, the contents of cadmium in hepatic, renal, pancreatic and testicular tissues was 4.1 times, 4.96 times, 4.1 times, and 3 times higher. respectively, than in Group I-E1. The difference for testicular samples was highly significant, those for pancreatic and renal samples were significant and that for hepatic samples non-significant. in the latter case apparently due to a higher variance. The differences were larger than those between Groups I-E1 and I-E2 resulting from different oral intake of cadmium. These results are indicative of additive effect of oral and respiratory intake of cadmium in the area with a high pollution rate. Airborne cadmium is contained in small particles that stick to the mucus covering the upper respiratory passages and are either swallowed to reach the gastrointestinal tract, or 
absorbed in the lung. A significant role of this way has been confirmed by Kessels and Wensing (1993). Malota et al. (1988) estimated that after oral intake. 3-8\% of cadmium were absorbed in the digestive tract. while the proportion of cadmium absorbed in the lung was $10-40 \%$ of the inhaled amount. The half-time of inhaled cadmium absorbed in the lung is 53 days. The biological half-time of cadmium in various mammalian organs has been estimated to 7-30 years.

It can be concluded from the results of our experiments that, in terms of clinical signs and metabolic profiles, chronic exposure of calves to low oral doses of cadmium ( 1 or $2 \mathrm{mg}$ per animal per day) had no adverse effect on the state of health. Increased AST activity indicated some alteration in the hepatic parenchyma in the experimental groups. The concentrations of cadmium in all the tissues under study were higher in the experimental than in the control groups. However, the concentrations in all the tissues were higher in calves receiving the lower dose and kept in the industrial area than in those kept in the ecologically favourable area irrespective of the administered doses. It is apparent that, in this case, the effect of environmental pollution was stronger than that of the oral administration. The only exception were the concentrations in the small intestine that reflected the doses administered in individual groups.

\section{Vliv chronické zátěže kadmiem na zdravotní stav a jeho kumulaci v orgánech telat}

Cílem sledování bylo zhodnocení vlivu životního prostředí a dlouhodobě podávaných nízkých dávek kadmia na zdravotní stav telat a obsah $\mathrm{Cd} v$ jednotlivých tkáních a orgánech. $\mathrm{V}$ pokusu probíhajícím $\mathrm{v}$ ekologicky čisté oblasti bylo 18 telat rozdělených do 3 skupin (skupina I-P 1 dostávala $\mathrm{Cd} 1 \mathrm{mg} / \mathrm{kus} / \mathrm{den}$, skupina I-P2 dostávala $\mathrm{Cd} 2 \mathrm{mg} / \mathrm{kus} / \mathrm{den}$, kontrola I-K). Kadmimum bylo podáváno po dobu 92 dní p. o. ve formě roztoku $\mathrm{CdCl}_{2}$. $\mathrm{V}$ pokusu probíhajícím $\mathrm{v}$ průmyslové oblasti bylo 16 telat rozdělených do 2 skupin (skupina II-P dostávala $1 \mathrm{mg} \mathrm{Cd} / \mathrm{kus} / \mathrm{den}$, kontrola II-K). Kadmium bylo podáváno po dobu 106 dní p. o. ve formě roztoku $\mathrm{CdCl}_{2}$. Po ukončení pokusu byla z každé skupiny odporažena 3 telata (ve skupině II-K pouze 2 telata) a byly odebrány vzorky jater, ledvin, myokardu, bránice, kosterní svaloviny, tenkého střeva, pankreatu a varlat. V jednotlivých tkáních byl stanoven obsah Cd metodou ETA AAS. V prủběhu pokusu byla rovněž odebírána krev na vyšetření metabolického profilu sledovaných telat (celková bílkovina, urea. glukóza. AST [aspartátaminotransferáza], GGT [gamaglutamyltransferáza]).

Dotace $\mathrm{Cd}$ neovlivnila sledované parametry metabolického profilu, pouze byla nesignifikantně zvýšená aktivita AST u pokusných skupin telat. V jednotlivých analyzovaných tkáních byly zjištěny následující prủměrné koncentrace ( \pm směrodatná odchylka) Cd $\vee \mu g . \mathrm{kg}^{-1}$ čerstvé tkáně (postupně podle skupin I-K; I-P1: I-P2: II-K; IIP): ledviny $(35,2 \pm 7.8: 326.0 \pm 144.5 ; 385,7 \pm 61.4 ; 129,4 \pm 6.8: 1618,7 \pm$ 393,2): játra (16,5 $\pm 5,6: 113,5 \pm 53,8: 138,4 \pm 32.6: 28,3 \pm 6,4 ;+65,3 \pm 141,5)$; pankreas $(2.6 \pm 0,3 ; 13.8 \pm 3,6 ; 20.5 \pm 6.6 ; 8,0 \pm 0.3 ; 57,1 \pm 16,5)$ : varle $(3.4 \overline{\mathrm{I}} 0,6$; $8.9 \pm 2,4: 6,8 \pm 0,6 ; 2.9 \pm 1,4 ; 27,2 \pm 0.7)$; střevo $(6,1 \pm 1,6 ; 15,1 \pm 9.5: 31,6 \pm 22,8$; $3.8 \pm 3.3: 17.7 \pm 6.1)$ : myokard $(0.6 \pm 0.1 ; 1.7 \pm 1.0: 2.8 \pm 0,4 ; 0.9 \pm 0.1 ; 4.6 \pm 0.2)$; bránice $(0,3 \pm 0,2 ; 2.1 \pm 0.7: 3,9 \pm 0,9 ; 2.4 \pm 1,4: 3.5 \pm 0.1)$; kosterní sval $(0.7 \pm 0,2$; $2.1 \pm 1,0 ; 2.4 \pm 1,0 ; 1,1 \pm 0,2 ; 3,2 \pm 1.9$ ). Rozdíly mezi pokusnými a kontrolními skupinami $v$ játrech, ledvinách, pankreatu a varlatech byly signifikantni. $Z$ uvedených výsledků vyplývá, že na koncentraci $C d$ ve tkáních s výjimkou tenkého střeva mělo větší vliv prostředí. ve kterém byl pokus realizován než výše dotace Cd. Chronická zátěž nízkými dávkami Cd neovlivnila negativně zdravotní stav telat. 


\section{References}

ANTONIOU. V.. TSOLKALI-PAPADOPOLOU. H. 1990: Cadmium concentrations in cattle tissues from animals bred at Sindos area of Thesaloniki. Bull. Hellenic Vet. Med. Soc. 41: 4()-43

CIBLLKA. J.. MADER. P.. SOVA. Z. 1986: Pohyb Pb. Cd a Hg v zemědělské výrobě a v biosfére. Praha - SZN. $160 \mathrm{p}$.

ELSENHANS. B.. KOLB. K.. SCHUMANN. K.. FORTH. W. 1994: The longitudinal distribution of cadmium. zinc. copper. iron and metallothionein in the small-intestinal mucosa of rats after administration of cadmium chloride. Biol. Trace Elem. Res. 41: 31-46

ELSENHANS. B.. SCHLLLER. N.. SCHUMANN. K.. FORTH. W. 1995: Oral and subcutaneus administration of cadmium chloride and the distribution of metallothionein and cadmium along the villus-crypt axis in rat jejunum. Biol. Trace Elem. Res. 42: 179-190

HORKYY. D.. LAUSCHOVA. I.. ILLEK. J.. PECHOVÁ. A.. ŠINDELÁR̆. M. 1997: Distribution of exogenous heavy metals in hepatocrtes of calf: a morphometric study. Scr. Med. (Brno) 70 (8): 409-416

HORKÝ. D.. ILLEK, J.. PECHOVÁ, A. 1998: Distribution of heavy metals and their ultrahistochemical determination in the organs of calves. Acta vet. Brno 67: 51-58

ILLEK. J.. DOCEEKALOV. A. H. 1993: Study of the interactions of cadmium and zinc in calves. In: Trace elements in man and animals - TEMA 8. Verlag Media Touristik. Gersciorf. pp. 583-584

JORHEM. L.. SLORACH. S.. SUNDSTROM. B.. OHLIN. B. 1991: Lead. cadmium arsenic and mercury inmeat. liver and kidney of Swedish pigs and cattle in 1984 - 88. Food Addit. Contam. 8: 201-212

KESSELS. B.. WENSING. T. 1993: Effects of environmental cadmium pollution in fattening of veal calves. Bull. Environ. Contam. Toxicol. 50: 561-564

KREUZER. W.. GABRIEL. W.. LUCKER. E.. ZERZAWY. H.. ROSOPULO, A. 1991: Untersuchungen zur gegenwartigen Cadmium- und Bleibelastung in Lebern und Nieren von Schlachtrindern. Fleischwirtschaft 71: 339-344

MALOTA. L.. RUSEK. T.. SMUTNÁ, M. 1988: Patobiochemické účinky vybraných rizikových prvků. In: Sborník Přednášek Stopové prvky v životním prostředi. potravinovém řetězci a biologickém materiálu. Lažánky 30.5.- 1.6.. P-ČSVTS při VSV v Brně. 42-47

MALÝ. M.. ZAHRADNICEK. L.. BALA. J. 1989: Návrh standardizované metody pro stanovení katalytické koncentrace AST v kreinim séru. Biochem. Clin. Bohemoslov. 18: 27-38

OHTA. H., SEKI. Y.. IMAMIYA. S., YOSHIKAWY. H. 1993: Influence of dietary selenium on chronic cadmium toxicity in mice. In: Trace elements in man and animals - TEMA 8. Verlag media touristik. Gersdorf. pp. 963965

PECHOVÁ, A. 1992: Diagnostika a prevence lipomobilizačního syndromu u dojnic v poporodním období. PhD. Thesis. Univ. Vet. Pharm. Sci., Brno, 170 p.

PECHOVÁ. A.. ILLEK. J.. PAVLATA. L.. SINDELÁR̆. M.. HORKÝ. D. 1998: Comparison of concentration Cd in tissue uf various categories of cattle. Acta vet. Brno 68: 103-107

RUSEK, T.. CELECHOVSKÁ. O. 1988: Vliv orální aplikace Cd na růstové parametry. na distribuci a redistribuci $\mathrm{Cu}$ a $\mathrm{Zn}$ u selat. In: Sborník Stopové prvky v životním prostředí. potravinovém řetězci a biologickém materiálu, Lažánky. P-ČSVTS při VŠV v Brně, 48-56

SMITH. R. H.. LEACH. R. M., MULLER. L. D.. GRIEL. L. C., BAKER. D. E. 1991 a: Effects of long-term dietary cadmium chlorid on tissue. milk and urine mineral concentrations of lactating dairy cow's. J. Anim. Sci. 69: 40884096

SMITH. R. H.. GRIEL. L. C.. MULLER. L. D. - LEACH. R. M.. BAKER. D. E. 1991 b: Effects of dietary cadmium chloride through gestation on blood and tissue metabolites of primigravid and neonatal dairy cattle. J. Anim. Sci. 69: $4078-4087$

NEATHERY. M. V., MILLER. V. J. 1975: Metabolism and toxicity of Cd. $\mathrm{Cu}$,and Pb in animals. J. Dairy Sci. 58: $1777-1781$

UNDERWOOD. E. J. 1977: Trace Elements in Human and Animals Nutrition, 4. Ed. New York, Academic Press. $545 \mathrm{p}$.

VRZGULA . L. et al. 1990: Poruchy látkového metabolismu hospodárskych zvierat a ich prevencia. 2th ed., Príroda. Bratislava. $503 \mathrm{p}$.

WHO. GEMS 1985: Global Environment Monitoring Systém. Guidelines for the study of dietary intakes of chemical contamitants. WHO Offset Publication No 87, Geneva

ZAHRADNÍCEK. L.. MALÝ. M.. CHROMÝ. V., VOZNÍCEK. J. 1986: Optimalizace stanovení katalytické koncentrace gama-glutamyltransferázy $v$ krevním séru a návrh standardizované metody. Biochem. Clin. Bohemoslov: 17: 87-96 